\title{
Not Known if KIT Mutation Analysis Was Performed
}

National Cancer Institute

\section{Source}

National Cancer Institute. Not Known if KIT Mutation Analysis Was Performed. NCI

Thesaurus. Code C160456.

An indication that it is not known whether KIT mutation analysis was performed during the study. 